\title{
ANALYSIS OF WHOLE BUILDING LIFE CYCLE ENVIRONMENTAL IMPACT ASSESSMENT (EIA) TOOLS
}

\author{
Thais Sartori ${ }^{1}$, Robin Drogemuller ${ }^{2}$, Sara Omrani $^{3}$ and Fiona Lamari ${ }^{4}$
}

\begin{abstract}
Environmental impact assessment (EIA) tools are key mechanisms that link the environmental context of a project to the decision-making framework. Life cycle assessment (LCA) and green building rating systems (GBRS) are the two approaches commonly used to holistically analyze the environmental performance of the whole building. While GBRS are mostly based on a checklist with many qualitative criteria, LCA compels the practitioner to base the analyses in numerical evidence, which facilitates the comparison between design choices. Some rating systems, such as LEED, BREEAM and Green Star, have been incorporating LCA as one of their criteria. This practice tends to increase in criteria-based tools, because of the market and governmental claims for better awareness of the construction industry ecological impacts. Therefore, the goal of this article is to discuss both whole building life cycle EIA tools, life cycle assessment (LCA) and green building rating system (GBRS), comparing their methodological concepts as well as the effort of combining both approaches. It was noticed that although there are many differences between EIA tools, the combination of both approaches would bring substantial benefits in identifying and mitigating the potential environmental impacts of buildings. Therefore, further research is needed to create a design process framework that unifies GBRS and LCA methodologies, providing a more comprehensive overview of a building's environmental impacts.
\end{abstract}

Keywords: Environment impact assessment (EIA), Life cycle assessment (LCA), Green building rating system (GBRS).

\section{INTRODUCTION}

The building industry brings substantial benefits to the world's society and economy, and it is a key element for sustainable development. But such benefits come with great environment impacts. It is estimated that $40 \%$ of the global greenhouse gas (GHG) emissions derives from the building sector, including the production of building materials and direct and indirect energy consumption (WBCSD, 2018). But such high environmental cost also comes with a great potential to shift this scenario, and buildings have become a target when it comes to GHG emissions reduction initiatives.

Environmental impact assessment (EIA) tools are developed to allow decision-makers to understand the impacts of their choices by connecting the environmental context to the decision-making framework (IEA, 2005). EIA tools can be divided into 3 main groups:

1 PhD Student, Queensland University of Technology, Brisbane, Australia, thais.goncalvessartori@hdr.qut.edu.au

2 Professor of Virtual Design \& Construction, Queensland University of Technology, Brisbane, Australia, robin.drogemuller@qut.edu.au

3 Lecturer in Virtual Design \& Construction, Queensland University of Technology, Brisbane, Australia, s.omrani@qut.edu.au

4 Lecturer in Construction Management, Queensland University of Technology, Brisbane, Australia, fiona.lamari@qut.edu.au 
(1) Energy and ventilation modelling;

(2) Life cycle assessment (LCA) tools;

(3) Passive tools, such as green building rating systems (GBRS), guidelines or checklists and Environmental Product Declarations (EPD)

Many studies of building impact assessment limited their analysis to the energy performance during the usage stage. But, especially with the advance of nearly zero energy building (NZEB), when the new technologies allow buildings to decrease energy usage and apply cleaner off-grid sources, embodied energy impacts derived from materials became a greater issue. Although operational energy still represents the greatest part on the building's life cycle, NZEB may lead to buildings with a higher portion of embodied energy and embodied carbon (Sartori and Hestnes, 2007). Therefore, in order to holistically analyze the performance of the whole building throughout its life cycle, LCA and passive tools from the above classification are used. In terms of passive tools, this article will focus on green building rating systems (GBRS) because it is the most commercially used whole building life cycle passive tool (Ade and Rehm, 2020).

Therefore, the goal of this article is to discuss the two types of whole building life cycle EIA tools, life cycle assessment (LCA) and green building rating system (GBRS), comparing their methodological concepts as well as the effort of combining both approaches.

\section{METHODOLOGICAL DIFFERENCES BETWEEN LCA AND GBRS}

\subsection{Life cycle assessment (LCA) of buildings}

The main goal of LCA is to address the potential environmental impacts of all inputs and output flows within a product's life cycle, from raw material acquisition, manufacture, use, maintenance, until end-of-life (Standard, 2006). Figure 1 shows the four phases with-in the methodology (Standard, 2006): goal and scope definition, inventory analysis, impact assessment, interpretation.

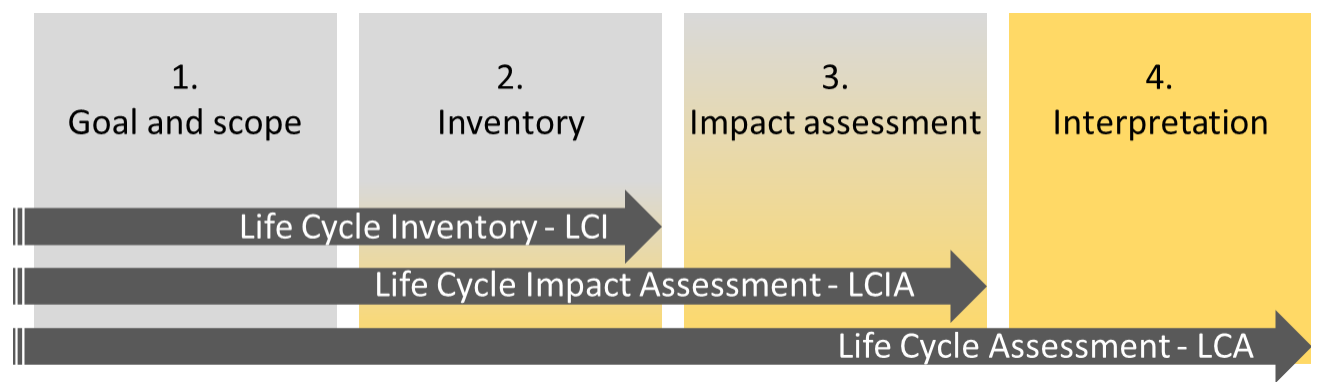

Figure 1: LCA phases

Studies that applied LCA methodology for buildings started in the '90s, and it has been growing ever since (Buyle et al., 2013), especially after the release of relevant standards (Standard, 2011). The British standard supports the decision making and documentation process and establishes the concepts to be followed by all practitioners, e.g. system boundaries, function units and reference study period. No regulation dictates the use of LCA methodology for the assessment of the impacts of construction-related activities (Larsson and Trusty 2004; Pomponi and Moncaster, 2018).

Because of the increasing interest of governmental groups in impacts of construction industry, LCA has become more attractive, particularly for materials manufacturers, through publication of environmental product declarations (EPD). EPDs communicate 
the environmental information of construction products, services and processes by quantification based on scientific data of all the input and output flows (Standard, 2014). In other words, EPD is a document owned by manufacturers that publicly dis-closures the LCA of their products. Although EPDs do not guarantee a more sustainable construction material, the understanding of the chemical emissions can diminish the impacts on the environment by motivating changes in the manufacture processes. Likewise, it gives the design decision-makers more understanding of their material choices, since EPDs allow them to make quantitative and scientific-based comparisons.

Although the publication of the standard represented a progress toward LCA of buildings, it is still difficult to compare the results of different assessments. The reasons include the geographical location of the building, which defines the weather, materials production chains, regional electricity mix, local regulations, in addition to technological, cultural and social differences (Buyle et al., 2013; Islam et al., 2015; Ortiz-Rodríguez et al., 2010). The significant variability of results found in many LCA studies (Pomponi and Moncaster, 2018; Dixit et al., 2010), indicates that there is still significant opportunity for more transparent and systematic assessments.

\section{$2.2 \quad 2.2 \quad$ Green building rating system}

GBRS are voluntary labelling schemes that measure the performance of green buildings by assigning credits and weights to environmental factors, sorted into different categories. The conception of GBRS was motivated by Green Building Councils (GBCs) around the world, aiming to communicate to the market the extent of a building's commitment to sustainable development (Ade and Rehm, 2020). Therefore, owners or developers voluntarily submit their building through a third part evaluation process to validate the green strategies applied. The result of this evaluation is often used by the building industry as a marketing strategy (Ade and Rehm, 2020).

Table 1 shows information about 6 different rating systems: Leadership in Energy and Environmental Design (LEED), Building Research Establishment Environmental Assessment Method (BREEAM), Green Star (GS), Haute Qualité Environnemen-tale (HQE), Comprehensive Assessment System for Built Environment Efficiency (CASBEE), and Deutsche Gesellschaft für Nachhaltiges Bauen (DGNB). These rating systems, besides being well known worldwide, are on the top list of the most cited in Scopus database (Bernardi et al., 2017; Li et al., 2017).

Energy, water and material are the most common categories analysed by rating systems, followed by site and indoor and outdoor environment quality. Energy is the category that has the greater weighting in most GBRS worldwide, accounting for $25 \%$ $30 \%$ of the total credits available (Illankoon et al., 2017; Mattoni et al., 2018; Shan and Hwang, 2018; He et al., 2018). LEED is one of the most energy-oriented systems, focused on the reduction of energy demand during operational stage by applying renewable energy sources and reducing cooling and heating loads (He et al., 2018). The concentration of credits in only one category might become an issue if a project achieves a certain certification level without any credits in another critical category, such as indoor environment quality (Wu et al., 2016).

Based on the main pillars of sustainability, rating systems mainly look at the environmental impacts (Doan et al., 2017), with reduced emphasis on analysing economic, social and institutional issues. Other aspects that need more attention in rating systems are prevention from environmental disasters, Life Cycle Assessment, reuse and retrofit (Mattoni et al., 2018). Since there isn't a common framework followed by all rating systems, studies show inconsistency on the results when analysing the same 
building with different certification process (Wallhagen and Glaumann, 2011). This is also true when comparing the performance of buildings located in different countries certified by the same rating system (Wu et al., 2016).

Table 1: Most cited GBRS

\begin{tabular}{|c|c|c|c|c|c|c|}
\hline & LEED & BREEAM & $\begin{array}{l}\text { Green } \\
\text { Star }\end{array}$ & HQE & CASBEE & DGNB \\
\hline Country & $\begin{array}{c}\text { Internation } \\
\quad \text { al }\end{array}$ & International & $\begin{array}{c}\text { Australi } \\
\text { a }\end{array}$ & $\begin{array}{c}\text { Internation } \\
\text { al }\end{array}$ & Japan & $\begin{array}{c}\text { Internation } \\
\text { al }\end{array}$ \\
\hline $\begin{array}{c}\text { Certificatio } \\
\text { n body }\end{array}$ & $\begin{array}{l}\text { US Green } \\
\text { Building } \\
\text { Council }\end{array}$ & $\begin{array}{l}\text { Building } \\
\text { Research } \\
\text { Establishme } \\
\text { nt group }\end{array}$ & $\begin{array}{c}\text { Green } \\
\text { Building } \\
\text { Council } \\
\text { of } \\
\text { Australi } \\
\text { a }\end{array}$ & $\begin{array}{l}\text { Cerway - } \\
\text { France }\end{array}$ & $\begin{array}{l}\text { Institute for } \\
\text { Building } \\
\text { Environmen } \\
t \text { and } \\
\text { Energy } \\
\text { Conservatio } \\
\mathrm{n} \text { (IBEC) }\end{array}$ & $\begin{array}{c}\text { German } \\
\text { Sustainable } \\
\text { Building } \\
\text { Council }\end{array}$ \\
\hline $\begin{array}{c}\text { First } \\
\text { version }\end{array}$ & 1998 & 1990 & 2002 & 1997 & 2004 & 2008 \\
\hline $\begin{array}{l}\text { Latest } \\
\text { update }\end{array}$ & 2019 & 2016 & 2017 & 2016 & 2014 & 2018 \\
\hline $\begin{array}{c}\text { Applicabilit } \\
y\end{array}$ & $\begin{array}{c}167 \\
\text { countries }\end{array}$ & 83 countries & $\begin{array}{c}1 \\
\text { country }\end{array}$ & $\begin{array}{c}16 \\
\text { countries }\end{array}$ & 1 country & $\begin{array}{c}20 \\
\text { countries }\end{array}$ \\
\hline
\end{tabular}

\subsection{Comparison analysis}

Regarding the methodological approach, one similarity between LCA and GBRS is the effect of human judgment when setting up the importance of each impact category. In rating systems, this decision is based on the category weighting, while in LCA this decision is made during the interpretation process. This human factor gives both assessments types a level of subjectivity, not based on scientific facts but on the developer or practitioner's value judgments (Ade and Rehm, 2020).

There are also many differences between both assessment tools. Criteria-based systems such as GBRS are more flexible in terms of which category a building is more likely to obtain credits. In other words, if a building does not perform so well in one category, it can be compensated by a higher performance in a different criterion. On the other hand, LCA calculates the impacts through the entire building life cycle, providing numerical evidence when comparing design choices (Mattoni et al., 2018). Another important difference relies on the way the outputs are informed. While in rating systems the results emphasize the improvements and advantages of the design decisions by providing a sustainability level, LCA outputs are focused on the environmental damage, such as natural resources depletion. This difference makes rating systems so appealing to the construction industry and allows green certifications to be used as a marketing strategy.

Although LCA calculates a building's environmental impact systematically and holistically, the analysis is made focused in a global or regional spectrum and the pros and cons of a new building in a community and neighbourhood context are of-ten 
ignored (Buyle et al., 2013). Specific local ecology and infrastructure impacts, such as the influence of the building on the micro-climate, wind and solar access, as well as the ability to modify the surrounding transportation system, isn't addressed with an LCA approach (IEA, 2005). Also, multi-criteria systems can inform a wider set of LCA impact categories (Collinge et al., 2015). Therefore, a more comprehensive environmental impact assessment tool would incorporate both measure-based methods, such as LCA and energy modelling, with qualitative criteria-based schemes (IEA, 2005; Buyle et al., 2013; Collinge et al., 2015).

\section{GBRS INTEGRATING LCA}

Following the construction industry transparency demand, Green Building Rating Systems (GBRSs) have also been incorporating Life Cycle Assessment (LCA) into their credits system. By introducing LCA as one of the criteria, rating systems in-crease the credits given to simulation of buildings performance, founding the assessment on empirical calculation methods. Such practice tends to increase in criteria-based tools, because of the market and governmental claim for a better awareness of the construction industry ecological burdens (Forsberg and von Malmborg, 2004). Apart from the wellknown check-lists practices, LCA compels GBRS practitioners to search for more authentic sustainable solutions, stimulating the search for innovations in the design. Yet, a robust and systematic LCA approach becomes a challenge when applied in a userfriendly framework such as criteria-based systems. Table 2 shows the LCA requirements for 6 different rating systems.

Since there are many types of certifications available, such as housing, interior design and in-use, this study focuses on the certification of new construction non-residential buildings, because that is the type of certification that encompasses a more diverse kind of buildings. Also, when available, the international version was chosen.

Among the main methodologies used by regulations and rating systems to address embodied impacts, the ones mostly used by GBRS are reporting, comparison and rating (Bionova, 2018). Considering the rating systems analyzed in this study, BREEAM is the only one that calculates the impacts construction projects with the aim of reporting it. The intention of BRE Global is to collect enough data to create a benchmark robust enough to be included on the future BREEAM updates (Establishment, 2016). The comparison methodology confronts the impacts of a design baseline with an environmentally improved proposed design. In this case, in order to get the desired results, the impacts of green decisions should also be acknowledged (Bionova, 2018). The baseline design is self-declared in LEED and "must be of comparable size, function, orientation, and operating energy performance" (USGBC, 2013). In Green Star the reference building is also self-declared but can also be a hypothetical building representing standard construction practices or an actual building constructed in the last five years similar to the proposed building (Australia, 2017). DGNB uses the rating methodology when LCA results are confronted with limit, target and reference values (DGNB, 2018). These reference values are self-proclaimed based on different types of buildings previously certified. Although it is a good start point to create benchmarks, it does not represent the entire construction industry practices, because it only considers buildings that were certified (Schlegl et al., 2019). 
Table 2: Life cycle assessment requirements based on green building rating system

\begin{tabular}{|c|c|c|c|c|c|c|}
\hline & $\begin{array}{l}\text { LEED v4.1 BC+D } \\
\text { New construction }\end{array}$ & $\begin{array}{c}\text { BREEAM International New } \\
\text { Constructions } 2016 \text { - Non-residential } \\
\text { fully fitted }\end{array}$ & $\begin{array}{l}\text { Green Star - } \\
\text { Design \& As } \\
\text { Built v1.2 }\end{array}$ & $\begin{array}{l}\text { HQE - } \\
\text { Nonresidential } \\
\text { building under } \\
\text { construction }\end{array}$ & $\begin{array}{l}\text { CASBEE for } \\
\text { buildings (new } \\
\text { construction) }\end{array}$ & $\begin{array}{c}\text { DGNB - New } \\
\text { construction } \\
\text { buildings - } \\
\text { commercial building }\end{array}$ \\
\hline Weight & $4.5 \%$ & $5.9 \%$ & $6.40 \%$ & $3,1 \%$ & $31.60 \%$ & $9.50 \%$ \\
\hline $\begin{array}{l}\text { Part of the } \\
\text { building assessed }\end{array}$ & $\begin{array}{l}\text { Structure and } \\
\text { enclosure }\end{array}$ & $\begin{array}{l}\text { _Mandatory: Envelope, structure, } \\
\text { finishes, upper floors, internal walls, } \\
\text { _Extra credits: Foundations, internal } \\
\text { finishes, building services and } \\
\text { landscaping. }\end{array}$ & - & $\begin{array}{l}\text { Structure or } \\
\text { finishing } \\
\text { _Structure and } \\
\quad \text { finishing }\end{array}$ & _Structure & $\begin{array}{c}\text { _Structure - } \\
\text { construction works: } \\
\text { _Structure - } \\
\text { services: }\end{array}$ \\
\hline $\begin{array}{c}\text { Characterization } \\
\text { model (1) }\end{array}$ & $\begin{array}{c}\text { TRACI, CML and } \\
\text { ReCiPe }\end{array}$ & - & $\begin{array}{l}\text { IPCC, WMO, } \\
\text { CML }\end{array}$ & - & - & CML \\
\hline $\begin{array}{l}\text { Building service } \\
\text { life cycle (years) }\end{array}$ & at least 60 years & 60 & 60 (suggested) & - & 60 & 50 \\
\hline Method & $\begin{array}{l}\text { Reporting or } \\
\text { comparison }\end{array}$ & Reporting & Comparison & Comparison & Comparison & Reporting or rating \\
\hline $\begin{array}{c}\text { Recognized } \\
\text { Software tool }\end{array}$ & $\begin{array}{l}\text { ATHENA Impact } \\
\text { Estimator, Envest 2, } \\
\text { LCA Design } \\
\text { SimaPro, GaBi }\end{array}$ & $\begin{array}{l}\text { ByggLCA, Conpact, OneClickLCA, } \\
\text { eTool, Green Guide, COCON, } \\
\text { ELODIE, MRPI Freetool MPG, nova } \\
\text { EQUER, SBS Building Sustainability, } \\
\text { Anavitor/ECO2. }\end{array}$ & - & $\begin{array}{l}\text { ELODIE, Team } \\
\text { Building }\end{array}$ & $\begin{array}{l}\text { Internally } \\
\text { developed } \\
\text { spreadsheet }\end{array}$ & - \\
\hline System boundary & Cradle - grave & _Flexible & Flexible & - & Cradle - grave & Cradle - grave \\
\hline Functional unit (2) & $\mathrm{ft} 2$ & - & $\mathrm{m} 2 \mathrm{GFA}$ & - & $\mathrm{Kg} \mathrm{CO} 2 / y r . m 2$ & $\mathrm{~m} 2 \mathrm{SA}^{*} \mathrm{a}$ \\
\hline Credits for EPDs & 1 & 1 & Up to 3 & Up to 7 & - & - \\
\hline
\end{tabular}

(1)TRACI (Bare et al., 2012); CML(University, 2019); ReCiPe (Goedkoop et al., 2013); IPCC (UNFCCC, 2019), WMO (Organization, 2020); (2) Gross floor area (GFA); suface area multiplied by the reference year considered (m2 SA*a) 


\section{- Leadership in Energy and Environmental Design (LEED)}

The latest update of LEED for new building design and construction, launched in November 2013, gives up to 5 points for building's life cycle impacts reduction, which represents $4.5 \%$ of all credits available (USGBC, 2013). It is possible to get these credits by renovating part of the building, reusing some materials or preforming an LCA of the structure and enclosure of the building. For the latter option, the assessment compares the final solution with a baseline building similar to the proposed design, demonstrating a minimum $10 \%$ reduction on the impact categories (USGBC, 2019). LEED's reference guide establishes some of the scope elements, such as a 60 years service life and a cradle to crave system boundary. It also indicates the appropriate impact assessment methods for North American projects and global characterization models that should be used in other parts of the word (USGBC, 2013).

\section{- Building Research Establishment Environmental Assessment Method (BREEAM)}

On the latest international version of BREEAM for new non-residential fully fitted buildings, there are up to 6 points when performing a whole-building LCA, which represents $5.9 \%$ of all credits available. BREEAM recognizes that LCA is a methodology that still needs to mature. Thereby, the credits available focus mostly on the robustness of the software tool, method, data and scope of the assessment, aiming to create benchmarks by collecting many building performance information (Establishment, 2016). The credits for performing an LCA is based on the quality of the assessment method and data, as well as on the scope of building elements included in the analyses (Establishment, 2016).

\section{- Green Star (GS)}

Green Star follows the same comparison methodology as LEED, in other words, the assessment results can be compared with a similar usage, construction and operation building, or with a hypothetical building that represents the contemporary standard practices (Australia, 2017). It is unclear what part of the building the practitioner should consider, and it is flexible on the system boundary, which may lead to a broad and unreliable results. But Green Star establishes that the performance should be peerreviewed and carried out by a verified experienced LCA practitioner. There are up to 7 points available for LCA that represents $6.4 \%$ of all credits available. The credits earned depend on the cumulative percentage impact reduction of 7 mandatory impact categories (Australia, 2017), but more points are available for additional life cycle impact report impacts.

\section{- Haute Qualité Environnementale (HQE)}

From the rating systems analyzed in this report, HQE is the only one that does not clearly implement LCA (Ismaeel, 2018). Although the practical guide for non-residential building under construction considers LCA as one of the methods to limit the environmental impact of the building, it does not specify the basic technical criteria, such as the impact categories and the system boundaries (Cerway, 2014). The assessment is made to create awareness of the environmental impacts caused by the chosen construction materials, and not to demonstrate a real reduction on the burdens. This lack 
of clear requirements may lead to misunderstandings and confusion, discouraging the practitioner to include this assessment as one of the certification criteria.

\section{- Comprehensive Assessment System for Built Environment Efficiency (CASBEE)}

The only impact category analyzed by CASBEE is the greenhouse gas emissions (Life Cycle CO2 - LCCO2). There are two ways of conducting a LCCO2. The first one is through standard calculation using references values of a level-3 performance building, and the other way is using individual calculation with a highly accurate LCCO2 estimative (IBEC, 2014). Using the first method, the CO2 emissions results are carried out automatically as the carbon-related criteria are filled out in a spreadsheet developed by CASBEE. In other words, the life cycle approach is not a criterion option because the carbon emissions levels are calculated along with the certification process. The cradle to grave approach estimates the embodied carbon of the main structural materials and uses $\mathrm{CO} 2$ emission coefficient to estimate the primary energy consumed during operation. The categories associated with LCCO2 are within Q2 - Quality of service, LR1 - Energy and LR2 - Resources \& materials, whose sum of points represents $31.6 \%$ of all certification credits. According to N. Lee, Tae, Gong, and Roh (Lee et al., 2017), CASBEE methodology is not able to investigate the benefits of green materials usage, due to its limited database that only brings major construction materials, namely, concrete, steel and wood.

\section{- Deutsche Gesellschaft für Nachhaltiges Bauen (DGNB)}

From all rating systems analyzed, DGNB has the most detailed description and specifications for the life cycle assessment category. One of the reasons is that the rating system focus on holistic approach, emphasizing the buildings performance through LCA (DGNB, 2019). The certification system provides reference values for most of the impact categories, based on a top-down statistical study conducted in 2017 gathering data from approximately 200 buildings (DGNB, 2018; Schlegl et al., 2019). It also establishes limit and target factor applied to the reference values. Points are awarded if the LCA results comply with the reference values, but highest points are earned if the impacts reach or fall below the target values. Additional points are awarded for buildings that focus on carbon-neutral in operation and construction, according to the agenda 2030 (Architecture2030, 2019). It is likely that this requirement will gradually become part of the certification in the upcoming versions (Braune et al., 2018).

\section{DISCUSSION}

The combination of different impact assessment methodologies, such as LCA and GBRS, is a holistic way to address the building's ecological burdens throughout its life cycle. But the existent tools still struggle to deliver an assessment framework that combines both approaches, especially during building's design process. Although there is an effort of some rating systems to increase the awareness of construction materials impacts, this is still an optional criterion. Perhaps, building's LCA methodology is still a long and extensive process for designers and building consultants, and the lack of a strong database to support benchmarks and reference values might discourage green building councils to better establish LCA as a certification pre-requisite.

As indicated above, CASBEE and DGNB are the ones among the rating systems analyzed that mandatorily considers LCA. These are also the rating systems that 
mandatorily considers the impacts from the energy demand during use, such as appliances, HVAC and lighting. For all the other rating systems analyzed, even when a cradle-grave approach is stated, they do not necessarily include the energy required for operational energy use, but only maintenance, material replacement and refurbishment. In fact, some rating systems give extra credits when including operational energy, such as Green Star and BREEAM. It is important to notice that the energy efficiency of the building also depends on the thermal and physical properties of the envelope's assembly. In other words, the choice of envelope material is strictly related to the building's energy efficiency during operation (Najjar et al., 2019). It is possible that an apparently nonenvironment friendly material provides the building with a great energy operational performance, but this analysis can only be made with a systematic LCA approach.

GBRS assessment considers quantitative (measure-based) and qualitative (featurespecific) criteria. Quantitative criterion is based on the building's performance supported by scientific techniques and can be more complicated to implement because it depends on specific calculation methods and simulations. Nevertheless, increasing quantitative measures in GBRS can increase the scientific value behind the credits (Collinge et al., 2015), while motivating innovation in the design (He et al., 2018). On the other hand, qualitative criterion points are granted whether a certain environmental issue is applied or not (He et al., 2018), which makes this type of credits simpler to assess. However, there are some drawbacks. He et al. (2018) pointed out that qualitative credits can be used as checklists by practitioners, limiting building design by indicating commonly used green techniques. Besides, it is more complicated to acknowledge the actual building performance only by choosing and applying different strategies.

Future research is needed in order to formulate a framework that considers both EIA tools approaches during the design process, so decision-makers are able to identify and reduce the building's impact on the environment.

\section{CONCLUSION}

This article analyzed two different whole building environmental impact assessment (EIA) tools, named life cycle assessment (LCA) and green building rating system (GBRS). The authors discussed their main characteristics, pointing out their disparities and similarities. Although there are many differences between the EIA tools mentioned, the combination of both approaches would bring substantial benefits in identifying and mitigating the building's potential environmental burdens.

All rating systems analyzed in this article include LCA in their certification scheme. Therefore, this article also discussed some of the rating system requirements for the LCA criterion, such as building's life service, functional unit and em-bodied emissions methodology. It was noticed that the awareness of embodied emissions tends to increase in rating systems, and the lack of a robust database to support benchmarks might discourage further developments.

In sum, further research is needed to create a design process framework that includes GBRS and LCA methodologies, providing a more comprehensive overview of the building's environmental impacts. 


\section{REFERENCES}

Ade R and Rehm M. (2020) The unwritten history of green building rating tools: a personal view from some of the 'founding fathers'. Building Research \& Information 48: 1-17.

Architecture2030. (2019) The 2030 challenges. Available at: https://architecture2030.org/2030_challenges/.

Australia GBCo. (2017) Green Star - Design \& As Built v. 1.2 Submission Guidelines.

Bare J, Young D and Hopton M. (2012) Tool for the reduction and assessment of chemical and other environmental impacts (TRACI) TRACI version 2.1 - User's guide. Cincinnati, OH: U.S Environmental Protection Agency, 24.

Bernardi E, Carlucci S, Cornaro C, et al. (2017) An analysis of the most adopted rating systems for assessing the environmental impact of buildings. 9: 1226.

Bionova. (2018) The Embodied Carbon Review. 73.

Braune A, Geiselmann D and Oehler CLS. (2018) Framework for "carbon-neutral buildings and sites" Preview version. Stuttgart, Germany: DGNB, 23.

Buyle M, Braet J and Audenaert A. (2013) Life cycle assessment in the construction sector: A review. Renewable and Sustainable Energy Reviews 26: 379-388.

Cerway. (2014) HQE Practical guide environmental performance building under construction. Practical guide to the assessment scheme for the environmental performance of non-residential building under construction. Paris - France, 405.

Collinge WO, Thiel CL, Campion NA, et al. (2015) Integrating Life Cycle Assessment with Green Building and Product Rating Systems: North American Perspective. International Conference on Sustainable Design, Engineering and Construction, ICSDEC 2015, May 10, 2015 - May 13, 2015. Chicago, United states: Elsevier Ltd, 662-669.

DGNB. (2018) DGNB System: Criteria set new construction building. Stuttgart, Germany: German Sustainable Building Council, 653.

DGNB. (2019) DGNB certification: a systematic approach to sustainability. Available at: https://www.dgnb.de/en/council/certification/.

Dixit MK, Fernández-Solís JL, Lavy S, et al. (2010) Identification of parameters for embodied energy measurement: A literature review. Energy and Buildings 42: 1238-1247.

Doan DT, Ghaffarianhoseini A, Naismith N, et al. (2017) A critical comparison of green building rating systems. Building and Environment 123: 243-260.

Establishment BR. (2016) BREEAM International New Construction. Technical Manual SD233 2.0. 454.

Forsberg A and von Malmborg F. (2004) Tools for environmental assessment of the built environment. Building and Environment 39: 223-228.

Goedkoop M, Heijungs R, Huijbregts M, et al. (2013) ReCiPe 2008. 133.

He Y, Kvan T, Liu M, et al. (2018) How green building rating systems affect designing green. Building and Environment 133: 19-31.

IBEC IfBEaEC. (2014) CASBEE for building (new construction). 257.

IEA IEA-. (2005) ANNEX 31 - Energy Related Environmental Impact of Buildings. Canada: Canada Mortgage and Housing Corporation.

Illankoon IMCS, Tam VWY, Le KN, et al. (2017) Key credit criteria among international green building rating tools. Journal of Cleaner Production 164: 209-220. 
Islam H, Jollands M and Setunge S. (2015) Life cycle assessment and life cycle cost implication of residential buildings-A review. Renewable and Sustainable Energy Reviews 42: 129-140.

Ismaeel WSE. (2018) Midpoint and endpoint impact categories in Green building rating systems. Journal of Cleaner Production 182: 783-793.

Larsson N and Trusty W. (2004) A review of LCADesign. Brisbane: CRC for Construction Innovation.

Lee N, Tae S, Gong Y, et al. (2017) Integrated building life-cycle assessment model to support South Korea's green building certification system (G-SEED). Renewable and Sustainable Energy Reviews 76: 43-50.

Li Y, Chen X, Wang X, et al. (2017) A review of studies on green building assessment methods by comparative analysis. Energy and Buildings 146: 152-159.

Mattoni B, Guattari C, Evangelisti L, et al. (2018) Critical review and methodological approach to evaluate the differences among international green building rating tools. Renewable and Sustainable Energy Reviews 82: 950-960.

Najjar M, Figueiredo K, Hammad AWA, et al. (2019) Integrated optimization with building information modeling and life cycle assessment for generating energy efficient buildings. Applied Energy 250: 1366-1382.

Organization WM. (2020) WMO/UNEP Scientific Assessment of Ozone Depletion: 1998. Available https://library.wmo.int/?lvl=notice_display\&id=15453\#.Xh2YRMgzY2w.

Ortiz-Rodríguez O, Castells F and Sonnemann G. (2010) Life cycle assessment of two dwellings: One in Spain, a developed country, and one in Colombia, a country under development. Science of the Total Environment 408: 2435-2443.

Pomponi F and Moncaster A. (2018) Scrutinising embodied carbon in buildings: The next performance gap made manifest. Renewable and Sustainable Energy Reviews 81: 2431-2442.

Sartori I and Hestnes AG. (2007) Energy use in the life cycle of conventional and lowenergy buildings: A review article. Energy and Buildings 39: 249-257.

Schlegl F, Gantner J, Traunspurger R, et al. (2019) LCA of buildings in Germany: Proposal for a future benchmark based on existing databases. Energy and Buildings 194: 342-350.

Shan M and Hwang B-g. (2018) Green building rating systems: Global reviews of practices and research efforts. Sustainable Cities and Society 39: 172-180.

Standard B. (2006) EN ISO 14040. Environmental management - Life cycle assessment Principles and framework. 32.

Standard B. (2011) EN 15978. Sustainability of construction works - Assessment of environmental performance of buildings - Calculation method. 64 .

Standard B. (2014) BS EN 15804:2012+A1:2013. Sustainability of constructionworks Environmentalproduct declarations - Corerules for the product categoryof construction products. 70.

UNFCCC. (2019) UNFCCC -- 25 Years of Effort and Achievement. Key Milestones in the Evolution of International Climate Policy. Available at: https://unfccc.int/timeline/.

University L. (2019) CML-IA Characterisation Factors. Available at: https://www.universiteitleiden.nl/en/research/research-output/science/cml-iacharacterisation-factors.

USGBC. (2013) LEED Reference guide for building design and construction. 
USGBC. (2019) LEED v4.1 Building design and construction. Getting started guide for beta participants. 251.

Wallhagen M and Glaumann M. (2011) Design consequences of differences in building assessment tools: A case study. Building Research and Information 39: 16-33.

WBCSD WBCfSD-. (2018) SBT4 buildings: A framework for carbon emissions management along the building and construction value chain. Available at: https://www.wbcsd.org/Programs/Cities-and-Mobility/SustainableCities/Science-based-targets/Resources/framework-carbon-emissionsmanagement-building-construction-value-chain.

Wu P, Mao C, Wang J, et al. (2016) A decade review of the credits obtained by LEED v2.2 certified green building projects. Building and Environment 102: 167-178. 